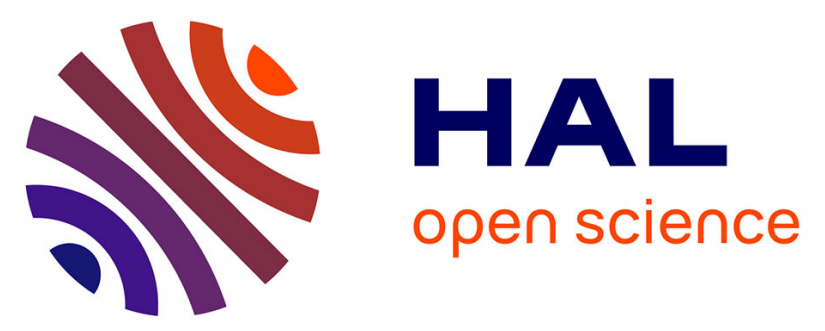

\title{
Antibacterial, antioxidant and cytotoxic activities of triterpenes and flavonoids from the aerial parts of Salvia barrelieri Etl.
}

\author{
Meryem Lehbili, Abdulmagid Alabdul Magid, Ahmed Kabouche, Laurence \\ Voutquenne-Nazabadioko, Amin Abedini, Hamid Morjani, Sophie C. Gangloff, \\ Zahia Kabouche
}

\section{To cite this version:}

Meryem Lehbili, Abdulmagid Alabdul Magid, Ahmed Kabouche, Laurence Voutquenne-Nazabadioko, Amin Abedini, et al.. Antibacterial, antioxidant and cytotoxic activities of triterpenes and flavonoids from the aerial parts of Salvia barrelieri Etl.. Natural Product Research, 2018, 32 (22), pp.2683-2691. 10.1080/14786419.2017.1378207 . hal-02008123

\section{HAL Id: hal-02008123 \\ https://hal.univ-reims.fr/hal-02008123}

Submitted on 22 Sep 2021

HAL is a multi-disciplinary open access archive for the deposit and dissemination of scientific research documents, whether they are published or not. The documents may come from teaching and research institutions in France or abroad, or from public or private research centers.
L'archive ouverte pluridisciplinaire HAL, est destinée au dépôt et à la diffusion de documents scientifiques de niveau recherche, publiés ou non, émanant des établissements d'enseignement et de recherche français ou étrangers, des laboratoires publics ou privés. 


\section{Antibacterial, antioxidant and cytotoxic activities of triterpenes and}

\section{flavonoids from the aerial parts of Salvia barrelieri Etl.}

Meryem Lehbilia, , Abdulmagid Alabdul Magid ${ }^{\mathrm{b}, *}$, Ahmed Kabouche ${ }^{\mathrm{a}}$, Laurence VoutquenneNazabadioko $^{\mathrm{b}}$, Amin Abedini ${ }^{\mathrm{b}, \mathrm{c}}$, Hamid Morjani ${ }^{\mathrm{d}}$, Sophie C. Gangloff ${ }^{\mathrm{c}}$ and Zahia Kabouche ${ }^{\mathrm{a}}$

${ }^{a}$ Université des frères Mentouri-Constantine, Département de chimie, Laboratoire d'Obtention des Substances Thérapeutiques (LOST), Campus Chaabet-Ersas, 25000 Constantine, Algeria

b ICMR-UMR CNRS 7312, Groupe Isolement et Structure, Campus Sciences, Bât. 18, BP 1039, 51687 Reims, France

${ }^{\text {c }}$ EA 4691 «Biomatériaux et inflammation en site osseux», Laboratoire de microbiologie, UFR de pharmacie, 1, rue du Maréchal-Juin, 51096 Reims, France

d MEDyC UMR CNRS 7369, URCA, Faculté de Pharmacie, SFR CAP Santé, 1, rue du MaréchalJuin, 51096 Reims, France

* Corresponding author.

E-mail address: abdulmagid.alabdulmagid@univ-reims.fr (A. Alabdul Magid) 


\section{Abstract}

From the aerial parts of Salvia barrelieri Etl. (Lamiaceae), six flavonoids and six triterpenes including a new compound $3 \beta$-acetoxy-olean-18-ene- $2 \alpha$-ol, were isolated. Their structures were established by the combination analyses of spectroscopy including 1D-, 2D-NMR, HRESIMS and in comparison with the reported data in the literature. The antibacterial evaluation of isolated compounds by bioautography on Staphylococcus aureus followed by the determination of MIC values of actives compounds by serial dilution technique against 5 bacteria revealed that epi-germanidiol (2), apigenin-7- $O$ - $\beta$-D-glucuronopyranoside (10) and cynaroside (12) were the most active against Enterococcus faecalis ATCC 1034, Staphylococcus aureus CIP 53.154, Escherichia coli CIP 54.127, Staphylococcus epidermidis and Pseudomonas aeruginosa ATCC 9027, with minimum inhibitory concentration values of 15.1 to $125 \mu \mathrm{g} / \mathrm{mL}$. Apigenin-7- $O$ - $\beta$-D-glucuronopyranoside (10) and cynaroside (12) exhibited moderate to good DPPH radical scavenging activity $\left(\mathrm{IC}_{50} 79.1\right.$ and $21.2 \mu \mathrm{g} / \mathrm{mL}$, respectively). The isolated compounds did not show significant tyrosinase inhibitory activities $\left(\mathrm{IC}_{50}>\right.$ at $\left.1.5 \mathrm{mg} / \mathrm{mL}\right)$. The cytotoxic activity of isolated compounds was evaluated against promyelocytic leukemia (HL60), human erythromyeloblastoid leukemia (K562) and fibrosarcoma (HT1080) cell lines. Compound 1, epi-germanidiol (2), germanicol (4) and micromeric acid (5) showed a moderate growth inhibitory activity against HL60, K562 and HT1080 cell lines ( $\mathrm{IC}_{50} 28.75$ to $\left.85.0 \mu \mathrm{M}\right)$.

Keywords: Salvia barrelieri, Lamiaceae, Triterpenoids, Flavonoids, Antibacterial Activity, Cytotoxic activity, Radical scavenging activity.

\section{Introduction}

The genus Salvia (Lamiaceae) comprises more than 900 species widely distributed, of which 23 species are distributed in Algeria [1]. Some Salvia species such as S. officinalis and $S$. miltiorrhiza have been applied as medicinal plants and used for the preparation of various 
remedies in various countries [2,3]. S. barrelieri Etl. has been used as diuretic, emmenagogue and to treat gastric disorders and microbial infections in Algeria [4].

The anticholinesterase, neuroprotective, anticancer, antiviral, anti-inflammatory, antioxidant, antibacterial and cytotoxic activities of Salvia plants were summarized in many reviews papers $[3,5]$. Other reviews were interested on diterpenoids and triterpenoids isolated from Salvia [6-8].

Salvia barrelieri is an herbaceous perennial plant found in northern Africa, Algeria, Morocco, Tunisia, and southwestern Spain. It grows 1-2 meters tall, with large, wavy, gray-green leaves. The inflorescence is a verticillaster and can grow nearly one meter tall, with flowers of light lavender or sky blue [9].

In continuation of our studies on the Salvia genus $[8,10,11,12]$, we have now investigated the aerial parts of $S$. barrelieri, from the root of which seven abietane diterpenoids have been previously isolated, and evaluated for their antioxidant activity $[4,11]$. Herein, we report the isolation and structural characterization of one new triterpene together with eleven known compounds from the aerial parts of this plant. Taking into account the use of this plant to treat gastric disorders and microbial infections, the antibacterial activities of isolated compounds were evaluated. In addition, the antioxidant, anti-inflammatory and cytotoxic activities of Salvia plants encouraged us to evaluate the DPPH radical scavenging rates and tyrosinase inhibitory activity. The cytotoxic activity of isolated compounds was evaluated against promyelocytic leukemia (HL60), human erythromyeloblastoid leukemia (K562) and fibrosarcoma (HT1080 cell lines).

\section{Results and discussion}

Chromatographic separations of exudate and the $80 \% \mathrm{EtOH}$ extract of the aerial parts of $S$. barrelieri led to the isolation of twelve compounds (1-12). Six triterpenoids (1-6), including a previously undescribed $3 \beta$-acetoxy-olean-18-ene-2 $\alpha$-ol (1) were isolated from the exudate 
whereas from the EtOH $80 \%$ extract, six flavonoid glycosides were isolated (7-12). The elucidation of their structures was performed by NMR analysis $\left({ }^{1} \mathrm{H}\right.$ and ${ }^{13} \mathrm{C}$ NMR, ${ }^{1} \mathrm{H}-{ }^{1} \mathrm{H}-$ COSY, HSQC, and HMBC) and high resolution mass spectrometry (HRESIMS).

The known compounds were identified as epi-germanidiol (2) [18], olean-18-ene- $1 \beta, 2 \alpha, 3 \beta$ triol (3) [19], germanicol (4) [20], micromeric acid (5) [21], ursolic acid (6) [22], salvigenin (7) [23], apigenin-7- $O$ - $\beta$-D-glucuronopyranoside methyl ester (8) [24], apigenin-7- $O$ - $\beta$-Dglucopyranoside (9) [25], apigenin-7- $O$ - $\beta$-D-glucuronopyranoside (10), apigenin (11) and cynaroside (12) [25,26] (Fig. 1). Their spectroscopic data were in perfect agreement with those reported in the literature.

Compound 1 was obtained as white solid. Its molecular formula was determined as $\mathrm{C}_{32} \mathrm{H}_{52} \mathrm{O}_{3}$ from the pseudo-molecular $[\mathrm{M}+\mathrm{Na}]^{+}$ion peak observed at $m / z 507.3820$ in the positive HRESIMS (calcd $\mathrm{C}_{32} \mathrm{H}_{52} \mathrm{O}_{3} \mathrm{Na}, 507.3814$ ). The ${ }^{1} \mathrm{H}$ NMR spectrum of $\mathbf{1}$ showed typical signals of eight tertiary methyl groups (each, 3H, s) at $\delta_{\mathrm{H}} 0.76(\mathrm{H}-27), 0.88(\mathrm{H}-24), 0.90(\mathrm{H}-23), 0.96$ (H-29), $0.97(\mathrm{H}-30), 0.98(\mathrm{H}-25), 1.04(\mathrm{H}-28)$ and $1.09(\mathrm{H}-26)$, one olefinic proton at $\delta_{\mathrm{H}} 4.89$ (brs, H-19), two oxygenated methines at $\delta_{\mathrm{H}} 3.84(\mathrm{td}, J=10.6,4.1 \mathrm{~Hz}, \mathrm{H}-2)$ and $4.52(\mathrm{~d}, J=10$ $\mathrm{Hz}, \mathrm{H}-3)$, and one acetoxy group at $\delta_{\mathrm{H}} 2.16(3 \mathrm{H}, \mathrm{s})$ (see experimental part). Analysis of the ${ }^{13} \mathrm{C}$ NMR and HSQC spectra of 1 revealed 32 signals, of which 30 were assigned to an aglycone and 2 belonged to acetoxy group ( $\delta_{\mathrm{C}} 172.4$ and 21.1). The aglycone of 1 was deduced to be a germanicol-type triterpene with two olefinic carbons of tri-substituted double bond ( $\delta_{\mathrm{C}} 129.8$ and 142.5), two oxygenated methine carbons $\left(\delta_{\mathrm{C}} 67.8\right.$ and 85.0$)$ and eight quaternary methyl carbons $\left(\delta_{\mathrm{C}} 14.5,16.0,17.4,17.8,25.2,28.4,29.1\right.$ and 31.3). All proton and carbon signals of $\mathbf{1}$ were assigned by analysis of 2D-NMR, including HSQC, HMBC and ${ }^{1} \mathrm{H}-{ }^{1} \mathrm{H}-\mathrm{COSY}$. The HMBC correlations of $\mathrm{H}_{3}-23$ and $\mathrm{H}_{3}-24$ to $\mathrm{C}-3\left(\delta_{\mathrm{C}} 85.0\right), \mathrm{C}-4\left(\delta_{\mathrm{C}} 39.3\right)$ and C-5 $\left(\delta_{\mathrm{C}} 55.4\right)$ indicated the location of the oxygenated carbon and gem-dimethyl groups at C-3 
and $\mathrm{C}-4$ in A ring, respectively. The correlation observed in the ${ }^{1} \mathrm{H}-{ }^{1} \mathrm{H}$ COSY spectrum between $\mathrm{H}-3\left(\delta_{\mathrm{H}} 4.52\right)$ and the second oxygenated methine $\left(\delta_{\mathrm{H}} 3.84\right)$ indicated that the second hydroxyl was located at C-2 $\left(\delta_{\mathrm{H}} 67.8\right)$ which was confirmed by the long rang correlations in HMBC spectrum between $\mathrm{H}-2\left(\delta_{\mathrm{H}} 3.84\right)$ and C-1 $\left(\delta_{\mathrm{C}} 48.3\right)$ and C-3 $\left(\delta_{\mathrm{C}} 85.0\right)$. Similarly, the HMBC correlations between $\mathrm{H}_{3}-25 / \mathrm{C}-1, \mathrm{C}-10$, C-9 and C-5, $\mathrm{H}_{3}-26 / \mathrm{C}-7, \mathrm{C}-8, \mathrm{C}-9$ and C-14, $\mathrm{H}_{3}-27 / \mathrm{C}-8, \mathrm{C}-13, \mathrm{C}-14$ and C-15, $\mathrm{H}_{3}-28 / \mathrm{C}-16, \mathrm{C}-17, \mathrm{C}-18, \mathrm{C}-22, \mathrm{H}_{3}-29$ and $\mathrm{H}_{3}-30$ /C-19, C20 , and C-21 confirmed some aspects of the structure. The HMBC correlation between the carbon methyl signal of C-27 at $\delta_{\mathrm{C}} 14.5$ and the proton at $\delta_{\mathrm{H}} 2.28(b r \mathrm{~d}(\mathrm{~J}=11.4 \mathrm{~Hz})$ attributed to the angular methine proton $\mathrm{H}-13$ and the $\mathrm{HMBC}$ correlations between this proton $\mathrm{H}-13$ and the two ethylenic carbons at $\delta_{\mathrm{C}} 129.8(\mathrm{C}-19)$ and $\delta_{\mathrm{C}} 142.5(\mathrm{C}-18)$ suggested a $\Delta^{18}$-unsaturated oleanene skeleton as in germanidiol or epi-germanidiol (2) [18]. The long range ${ }^{4} J{ }^{1} \mathrm{H}-{ }^{1} \mathrm{H}$ COSY correlation observed between $\mathrm{H}-19$ and $\mathrm{H}-13$ in addition to the HMBC correlations observed between H-19/C-13, C-17, C-20, C-21, C-29, and C-30 confirmed the position of the double bond at C-18/C-19. The acetoxy group was assigned at C-3 as deduced from the HMBC correlation observed between $\mathrm{H}-3$ and $\mathrm{H}_{3}$-acetyl to the carboxyl carbon at $\delta_{\mathrm{C}} 172.4$. Thus, the aglycone of $\mathbf{1}$ was considered to be 3-acetoxy-olean-18-ene-2-ol. The 2- $\alpha$ and 3- $\beta$ orientations of hydroxy and acetoxy groups were deduced from the value of the vicinal coupling constant $\left(J_{2-3}=10.0 \mathrm{~Hz}\right)$ and by comparison with spectroscopic data with those reported in the literature for compounds possessing $3 \beta$-acetoxyl and $2 \alpha$-hydroxyl substitution $\left(J_{\mathrm{H} 3 \alpha / \mathrm{H} 2 \beta}=10.0 \mathrm{~Hz}\right)[27]$ and with epi-germanidiol $\left(2 \alpha, 3 \beta\right.$-di-OH, $\left.J_{2-3}=10 \mathrm{~Hz}\right)$ and germanidiol $\left(2 \alpha, 3 \alpha\right.$-di-OH, $\left.J_{2-3}=3 \mathrm{~Hz}\right)$ [18]. The $\beta$ orientation of $\mathrm{H}-13$ was deduced by comparison of the vicinal coupling constant value and by comparison with spectroscopic data with those reported in the literature of germanidiol and epi-germanidiol (2) [18]. The large vicinal coupling constant value between $\mathrm{H}-12 \mathrm{ax}$ and $\mathrm{H}-13\left(J_{12 \mathrm{ax}-13}=11.4 \mathrm{~Hz}\right)$ suggested a quasi trans-diaxial relationship, like in $2 \alpha, 3 \beta, 21 \beta, 23$-tetrahydroxyolean-18-en-28-oic [17]. 
Consequently, the structure of 1 was elucidated as $3 \beta$-acetoxy-olean-18-ene- $2 \alpha$-ol, or 3 -acetyl epi-germanidiol.

The antibacterial activity of the exudate and the $80 \% \mathrm{EtOH}$ extract obtained from the aerial parts of $S$. barrelieri were initially tested for their antibacterial capacity using TLC bioautography method against $S$. aureus CIP 53.154, a Gram positive cocci bacterium frequently found on the skin and in the respiratory tract and that can be responsible for nosocomial infections [13]. Currently its resistance to antibiotics is an acute problem for the treatment of patients. The results showed good activity for the $80 \% \mathrm{EtOH}$ extract and a milder activity for the exudate by comparison with the reference gentamicin. Subsequently, the test was repeated for compounds $\mathbf{1 - 1 2}$ isolated from the $80 \% \mathrm{EtOH}$ extract and the exudate. Compounds $\mathbf{2}, \mathbf{4}, \mathbf{5 - 8}, \mathbf{1 0 - 1 2}$ were the only active compounds as revealed by the white inhibition zones observed on the TLC plate around all compound spots. The minimum inhibitory concentration values (MIC) of these compounds were measured by a serial dilution technique using 96-well microliter plates against three Gram-positive (E. faecalis ATCC 1034, S. aureus CIP 53.154 and S. epidermidis) and two Gram negative (E. coli CIP 54.127 and $P$. aeruginosa ATCC 9027) bacteria (Table 1). The results showed a high inhibitory effect of compound $\mathbf{1 0}$ against P. aeruginosa (MIC $15.1 \mu \mathrm{g} / \mathrm{mL}$ ), E. faecalis, S. epidermidis and $E$. coli (MIC $31.2 \mu \mathrm{g} / \mathrm{mL}$ ). Compound 12 was also active against these four bacteria (MIC $31.2 \mu \mathrm{g} / \mathrm{mL}$ ). The triterpenes $\mathbf{1 - 6}$ were less active compared to flavonoids $\mathbf{1 0}$ and $\mathbf{1 2}$. Only compound 6 showed a high antibacterial activity against E. faecalis (MIC $31.2 \mu \mathrm{g} / \mathrm{mL}$ ). Triterpene $\mathbf{2}$ showed also good antibacterial activity against the five tested bacteria with MIC values ranging from 62.5 to $125 \mu \mathrm{g} / \mathrm{mL}$ (Table 1). A moderate antibacterial activity against the five tested bacteria with MIC values ranging from 125 to $250 \mu \mathrm{g} / \mathrm{mL}$ was obtained with compounds $\mathbf{5}$ and $\mathbf{8}$. 
The DPPH radical scavenging activity of $80 \%$ EtOH extract and exudate obtained from the aerial parts of Salvia barrelieri was measured. In this assay, antioxidants were able to reduce the stable radical DPPH to the yellow-colored diphenyl-picrylhydrazine. Only the $80 \% \mathrm{EtOH}$ showed a DPPH radical scavenging activity $\left(\mathrm{IC}_{50} 50.1 \mu \mathrm{g} / \mathrm{mL}\right)$. Subsequently, the test was repeated for compounds 7-12 isolated from this extract. Only compounds $\mathbf{1 0}$ and $\mathbf{1 2}$ exhibited moderate to good DPPH radical scavenging activity ( $\mathrm{IC}_{50} 79.1$ and $21.2 \mu \mathrm{g} / \mathrm{mL}$, respectively) compared with the reference ascorbic acid $\left(\mathrm{IC}_{50} 11.2 \mu \mathrm{g} / \mathrm{mL}\right)$. The five other compounds showed low or no antiradical activity.

The tyrosinase inhibitory activity of the $80 \% \mathrm{EtOH}$ extract and the exudate obtained from the aerial parts of $S$. barrelieri was tested. The $80 \%$ EtOH extract showed a low tyrosinase inhibitory activity at the dose of $1.5 \mathrm{mg} / \mathrm{mL}$ ( $27 \%$ inhibition). The test was repeated for compounds 7-12 isolated from this extract and 50\% inhibition was not achieved at the concentration of $1.5 \mathrm{mg} / \mathrm{mL}$. Kojik acid was used as positive control ( $\mathrm{IC}_{50} 20 \mu \mathrm{g} / \mathrm{mL}$ ).

The cytotoxic activity of compounds 1-12 was evaluated in vitro using two tumor cell lines, promyelocytic leukemia (HL60), human erythromyeloblastoid leukemia (K562) and fibrosarcoma (HT1080). The resulting $\mathrm{IC}_{50}$ values are listed in table 1 . Compounds $\mathbf{2 , 4}$ and $\mathbf{5}$ showed a moderate cytotoxic activity against HL60 ( IC $_{50} 54.0,42.0,52.0 \mu \mathrm{M}$, respectively) and against K562 cell lines ( $\mathrm{IC}_{50} 85.0,82.0,82.0 \mu \mathrm{M}$, respectively). Compound 1 showed good cytotoxic activity against HT1080 ( IC $_{50} 28.75 \mu \mathrm{M}$ ) whereas compounds $\mathbf{2}, \mathbf{4}$ and $\mathbf{5}$ showed moderate cytotoxic activity against $\mathrm{HT} 1080$ ( $\mathrm{IC}_{50} 50,37.5$ and $41.5 \mu \mathrm{M}$, respectivly).

\section{Experimental}

\subsection{General experimental procedures}


HRESIMS experiments were performed using a Micromass Q-TOF micro instrument (Manchester, UK). Optical rotations of pure compounds were measured in $\mathrm{CHCl}_{3}$ using a Perkin-Elmer 341 Polarimeter. NMR spectra were recorded in $\mathrm{CD}_{3} \mathrm{OD}$ or $\mathrm{CDCl}_{3}$ on a Bruker Avance III 500 spectrometer $\left({ }^{1} \mathrm{H}\right.$ at $500 \mathrm{MHz}$ and ${ }^{13} \mathrm{C}$ at $\left.125 \mathrm{MHz}\right)$. 2D-NMR experiments were performed using standard Bruker microprograms (TopSpin 3.2 software). Flash chromatography was carried out on a Grace Reveleris system equipped with dual UV and ELSD detection using Grace ${ }^{\circledR}$ cartridges (Silica gel or RP-C 18 ). HPLC separations were performed on a Dionex apparatus equipped with an ASI-100 autosampler, an Ultimate 3000 pump, a STH 585 column oven, a diode array detector UVD 340S and a Chromeleon software. A prepacked RP-C 18 column (Phenomenex 250 x $15 \mathrm{~mm}$, Luna $5 \mu$ ) was used for semi-preparative HPLC. The eluting mobile phase consisted of $\mathrm{H}_{2} \mathrm{O}$ with TFA $(0.0025 \%)$ and $\mathrm{CH}_{3} \mathrm{CN}$ with a flow rate of $5 \mathrm{~mL} / \mathrm{min}$ and the chromatogram was monitored at 205 and 210 nm. Thin-layer chromatography (TLC) was carried out using silica gel $60 \mathrm{~F}_{254}$ pre-coated aluminium plates $(0.2 \mathrm{~mm}$, Merck). After developing with solvent systems, spots were visualized under UV light (254 and $366 \mathrm{~nm}$ ) and sprayed with $50 \% \mathrm{H}_{2} \mathrm{SO}_{4}$ followed by heating. An Armen instrument equipped with an AP 250/500 pump, ACC 250/500 sampler, and a Merck UV-detector K-2501 was used for preparative HPLC. A Lichrospher RP18

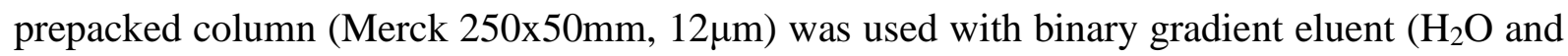
$\mathrm{CH}_{3} \mathrm{CN}$ ) and a flow rate of $50 \mathrm{~mL} / \mathrm{min}$; the chromatogram was monitored at $\lambda 250 \mathrm{~nm}$.

\subsection{Plant material}

The aerial parts of Salvia barrelieri Etl. (Lamiaceae) were collected from Constantine (NorthEastern of Algeria), in April 2014 and it was authenticated by Mr. Kamel Kabouche. A voucher specimen (LOST.Sb.04.14) was deposited at the University of Constantine, Algeria.

\subsection{Extraction and isolation}


The fresh aerial parts of $S$. barrelieri $\left(7 \mathrm{~kg}\right.$ ) were first immersed in $\mathrm{CHCl}_{3}$ for $20 \mathrm{~s}$. After filtration and evaporation of the solvent under reduced pressure, $48 \mathrm{~g}$ of exudate were obtained. Then, the powdered air-dried aerial parts were macerated in $\mathrm{EtOH}-\mathrm{H}_{2} \mathrm{O}(8: 2,7 \mathrm{~L})$; three time at room temperature. The combined extracts were concentrated under reduced pressure and the residue was suspended in $\mathrm{H}_{2} \mathrm{O}(1 \mathrm{~L})$, to be partitioned successively with $\mathrm{CHCl}_{3}$, EtOAc and $n$-BuOH $(3 \times 300 \mathrm{~mL}$ each $)$, to yield respectively $1.8,2.7$ and $11 \mathrm{~g}$ of each fraction.

A portion of the exudate (10 g) was fractionated by silica gel-vacuum liquid chromatography (VLC) using a step-gradient solvent system from $100 \%$-hexane to $100 \%$ EtOAc with a $10 \%$ increment to obtain 21 fractions [E1-E21]. Fraction E5 (129 mg) was subjected to flash chromatography on RP18 using a gradient $90-100 \%$ of $\mathrm{MeOH}$ in water in $30 \mathrm{~min}$, affording compound 4 (32 mg). Fraction E11 (380 mg) was further purified by flash chromatography on RP18, eluted with $\mathrm{MeOH}$ from 80 to $100 \%$ in water, to yield compound 1 (67 mg). Fraction E14 (1.28 g) was also subjected to flash chromatography on RP18 eluted with the same system of the previous fraction (E11), to give compounds $2(23.3 \mathrm{mg}), 5(10.5 \mathrm{mg})$ and $\mathbf{6}(8$ $\mathrm{mg})$. Compound $\mathbf{3}(1.5 \mathrm{mg})$ was obtained from the flash chromatography over silica gel of the fraction E16 (1.47 g), eluted by gradient system toluene-acetone (100:0-80:20).

A part of the $n-\mathrm{BuOH}$ fraction (2 g) was submitted to a VLC over RP18 eluted with $\mathrm{MeOH}: \mathrm{H}_{2} \mathrm{O}$ solvent system (from $0 \% \mathrm{MeOH}$ to $100 \% \mathrm{MeOH}$ ) to give 6 fractions. The $60 \%$ $\mathrm{MeOH}$ fraction (310 mg) was subjected to flash chromatography over silica gel, eluted by a gradient system of $\mathrm{CHCl}_{3}-\mathrm{MeOH}$ (100:0-90:10), in $25 \mathrm{~min}$, affording compounds 7 (4.6 mg), $8(6.8 \mathrm{mg}), \mathbf{9}(18.5 \mathrm{mg})$ and $11(6.4 \mathrm{mg})$. The $20 \% \mathrm{MeOH}$ fraction (200 mg) was further subjected to HPLC preparative eluted by $\mathrm{CH}_{3} \mathrm{CN}: \mathrm{H}_{2} \mathrm{O}$ (from $0 \%$ to $100 \% \mathrm{CH}_{3} \mathrm{CN}$ ), to give compound 10 (13.8 mg). The first sub-fraction $(98.7 \mathrm{mg}$ ) was purified by semi-prep HPLC eluted with isocratic system $\left(22 \% \mathrm{CH}_{3} \mathrm{CN}\right)$, to yield compound $12\left(\mathrm{t}_{R} 19.0 \mathrm{~min}, 2 \mathrm{mg}\right)$. 


\subsection{Antibacterial assay}

An immersion bioautography method was adopted to identify the most promising compounds as previously described by Abedini et al. $[13,14]$. Gentamicin was used as a positive control. A serial dilution technique using 96-well microliter plates was used to determine the MIC values of the active compounds revealed by bioautography. MIC values were determined as the lowest concentrations of samples having an inhibitory effect on bacteria growth. This test was performed in duplicates. Gentamicin and vancomycin were used as positive controls.

\subsection{DPPH radical scavenging activity}

The scavenging activity of isolated compounds against DPPH was investigated by spectrophotometric methodology [15]. Ascorbic acid was used as positive control.

\subsection{Tyrosinase enzyme assay}

Tyrosinase activity inhibition was determined spectrophotometrically according to the method previously described by Tadrent et al. [16]. Kojic acid was used as positive control agent.

\subsection{Cytotoxicity assay}

Compounds 1-12 were tested for their cytotoxicity against promyelocytic leukemia (HL60), human erythromyeloblastoid leukemia (K562) and fibrosarcoma HT1080 cells by mean of the MTT method as previously described by Gossan et al. [17].

3.8. 3 $\beta$-acetoxy-olean-18-ene-2 $\alpha$-ol (compound 1): $[\alpha]^{20}{ }_{\mathrm{D}}-3\left(c 0.1, \mathrm{CHCl}_{3}\right) ;{ }^{1} \mathrm{H} \mathrm{NMR}(500$ $\left.\mathrm{MHz}, \mathrm{CDCl}_{3}\right): \delta_{\mathrm{H}} 0.98(\mathrm{~m}, \mathrm{H}-1), 2.23(\mathrm{dd}, J=12.3,4.2 \mathrm{~Hz}, \mathrm{H}-2 \mathrm{a}), 3.84(\mathrm{td}, J=12.3,4.1 \mathrm{~Hz}$ H-2b), 4.52 (d, $J=10.0 \mathrm{~Hz}, \mathrm{H}-3), 0.94$ (m, H-5), 1.43, 1.53 (each m, H2-6), 1.37, 1.52 (each m, $\mathrm{H}_{2}-7$ ), 1.36 (m, H-9), 1.37, 1.60 (each m, $\mathrm{H}_{2}-11$ ), 1.20, 1.51 (each m, $\mathrm{H}_{2}-12$ ), 2.28 (brd, $J=11.4 \mathrm{~Hz}, \mathrm{H}-13), 1.21(\mathrm{~m}, \mathrm{H}-15 \mathrm{a}), 1.82(\mathrm{td}, J=13.6,4.8 \mathrm{~Hz}, \mathrm{H}-15 \mathrm{~b}), 1.42,1.46$ (each m, $\mathrm{H}_{2}-16$ ), 4.89 (brs, H-19), 1.43, 1.47 (each m, $\mathrm{H}_{2}-21$ ), 1.34, 1.45 (each m, $\mathrm{H}_{2}-22$ ), 0.90 (s, 
$\left.\mathrm{H}_{3}-23\right), 0.88$ (s, $\left.\mathrm{H}_{3}-24\right), 0.98$ (s, $\left.\mathrm{H}_{3}-25\right), 1.09$ (s, $\left.\mathrm{H}_{3}-26\right), 0.76$ (s, $\left.\mathrm{H}_{3}-27\right), 1.04$ (s, $\mathrm{H}_{3}-28$ ), 0.96 (s, H3-29), 0.97 (s, H3-30), 2.16 (s, $\mathrm{H}_{3}$-acetyl); ${ }^{13} \mathrm{C}$ NMR $\left(125 \mathrm{MHz}, \mathrm{CDCl}_{3}\right): \delta_{\mathrm{C}} 48.3$ (C-1), 67.9 (C-2), 85.0 (C-3), 39.3 (C-4), 55.5 (C-5), 18.2 (C-6), 34.4 (C-7), 40.8 (C-8), 51.1 (C-9), 38.4 (C-10), 21.3 (C-11), 26.1 (C-12), 38.3 (C-13), 43.4 (C-14), 27.5 (C-15), 37.7 (C16), 34.3 (C-17), 142.5 (C-18), 129.9 (C-19), 32.4 (C-20), 33.3 (C-21), 37.4 (C-22), 28.4 (C23), 17.5 (C-24), 17.9 (C-25), 16.1 (C-26), 14.6 (C-27), 25.2 (C-28), 31.3 (C-29), 29.2 (C-30), 172.4 (acetyl-C-1), 21.2 (acetyl-C-2); HRESIMS m/z: $507.3820 \quad[\mathrm{M}+\mathrm{Na}]^{+}$(calcd for $\left.\mathrm{C}_{32} \mathrm{H}_{52} \mathrm{O}_{3} \mathrm{Na}, 507.3814\right)$.

\section{Conclusions}

The present paper reported the isolation and structural characterization of a new triterpene $3 \beta$ acetoxy-olean-18-ene- $2 \alpha$-ol, along with eleven known compounds from the aerial parts of $S$. barrelieri. The antibacterial potential evaluated initially by using TLC bioautography method followed by a serial dilution technique to determine the minimum inhibitory concentration (MIC) showed a high activity for compounds 2, 10 and 12. The DPPH scavenging and tyrosinase inhibitory effects of the exudate, the $80 \%$ EtOH extract and flavonoids (7-12) isolated from the $80 \% \mathrm{EtOH}$ extract were evaluated. Only the $80 \% \mathrm{EtOH}$ extract showed moderate antioxidant activity and low tyrosinase inhibitory activity. Flavonoids $\mathbf{1 0}$ and $\mathbf{1 2}$ exhibited moderate to good DPPH radical scavenging activity. Flavonoids 7-12 did not show significant tyrosinase inhibitory activity. The cytotoxic activity of isolated compounds, evaluated in vitro using two tumor cell lines, the promyelocytic leukemia (HL60), the human erythromyeloblastoid leukemia (K562) and fibrosarcoma (HT1080), showed that compounds 1, 2, 4 and 5 had a moderate cytotoxic activity. The overall results may support the use of this plant in traditional medicine for the treatment of gastric disorders and microbial infections 


\section{Supporting Information}

Supplementary materiel relating to the NMR and HR-ESI-MS spectra of new compound $\mathbf{1}$ and NMR data of 2-12.

\section{Acknowledgements.}

The authors are grateful to MESRS Algeria for the PNE grant to Ms Meryem Lehbili, to CNRS, Conseil Régional de Champagne Ardenne (CRCA), Conseil Général de la Marne, Ministry of Higher Education and Research (MESR) in France, and to the PlANET CPER project for financial support.

\section{Supporting Information}

HR-ESI-MS spectra and 1D and 2D NMR of 1 and NMR data of 2-12.

\section{References}

[1] Kabouche A, Kabouche Z. 2008. Bioactive diterpenoids of Salvia Species. Stud Nat Prod Chem. 5:753-833.

[2] Wang X, Morris-Natschke SL, Lee KH. 2007. New developments in the chemistry and biology of the bioactive constituents of Tanshen. Med Res Rev. 27:133-148.

[3] Wu YB, Ni ZY, Shi QW, Dong M, Kiyota H, Gu YC, Cong B. 2012. Constituents from Salvia species and their biological activities. Chem Rev. 112:5967-6026.

[4] Kolak U, Kabouche A, Ozturk M, Kabouche Z, Topcu G, Ulubelen A. 2009. Antioxidant diterpenoids from the roots of Salvia barrelieri. Phytochem Anal. 20:320-327.

[5] Jassbi AR, Zare S, Firuzi O, Xiao J. 2015. Bioactive phytochemicals from shoots and roots of Salvia species. Phytochem Rev. 15:829-867.

[6] Gorai D, Jash SK, Roy R. 2016. Ursane's of the genus Salvia. Indo Am J Pharm Res. 6:4242-4253. 
[7] Jash SK, Gorai D, Roy R. 2016. Salvia genus and triterpenoids. IJPSR. 7:4710-4732.

[8] Kabouche A, Kabouche Z, Touzani R, Bruneau C. 2008. Diterpenes and sterols from the roots of Salvia verbenaca subsp. clandestina. Chem Nat Compds 44: 824-825.

[9] Quezel P, Santa S. 1963. New flora of Algeria and the Southern Desert Regions. Vol. 1-2. CNRS, Paris.

[10] Kabouche A, Boutaghane N, Kabouche Z, Seguin E, Tillequin F, Benlabed K. 2003. Components and antibacterial activity of the roots of Salvia jaminiana. Fitoterapia 76: 450452.

[11] Kabouche A, Kabouche Z, Öztürk M, Kolak U, Topçu G. 2007. Antioxidant abietane diterpenoids from Salvia barrelieri. Food Chem. 102:1281-1287.

[12] Lakhal H, Kabouche A, Alabdul Magid A, Voutquenne-Nazabadioko L, Harakat D, Kabouche Z. 2014. Triterpenoids from Salvia argentea var. aurasiaca (Pomel) Batt. \& Trab. and their chemotaxonomic significance. Phytochemistry 102:145-151.

[13] Abedini A, Chollet S, Angelis A, Borie N, Nuzillard JM, Skaltsounis AL, Reynaud R, Gangloff SC, Renault JH, Hubert J. 2016. Bioactivity-guided identification of antimicrobial metabolites in Alnus glutinosa bark and optimization of oregonin purification by centrifugal partition chromatography. J chromatogr B. 1029-1030, 121-127.

[14] Benmerache A, Alabdul Magid A, Berrehel D, Kabouche K, Voutquenne-Nazabadioko L, Messaili S, Abedini A, Harakat D, Kabouche Z. 2016. Chemical composition, antibacterial, antioxidant and antityrosinase activities of glycosides from aerial parts of Eryngium tricuspidatum L. Phytochem lett. 18:23-28.

[15] Benmerache A, Benteldjoune M, Alabdul Magid A, Abedini A, Berrehal D, Kabouche A, Gangloff SC, Voutquenne-Nazabadioko L, Kabouche Z. 2017. Chemical composition, 
antioxidant and antibacterial activities of aerial parts of Tamarix balansae J. Gay. Nat Prod Res. 10:1-8.

[16] Tadrent W, Alabdul Magid A, Kabouche A, Harakat D, Voutquenne-Nazabadioko L, Kabouche Z. 2016. A new sulfonylated flavonoid and other bioactive compounds isolated from the aerial parts of Cotula anthemoides L. Nat Prod Res. 28:1-9.

[17] Gossan DPA, Alabdul Magid A,Yao-Kouassi, PA, Josse J, Gangloff SC, Morjani H, Voutquenne-Nazabadioko L. 2016. Antibacterial and cytotoxic triterpenoids from the roots of Combretum racemosum. Fitoterapia 110:89-95.

[18] Ageta H, Ageta T. 1984. Erecaseous constituents : Seventeen triterpenoids isolated from the buds of Rhododendro macrocepalum . Chem Pharm Bull. 32:369-372.

[19] Habibi Z, Cheraghi Z, Ghasemi S, Yousefi S, A new highly hydroxylated triterpene from Salvia atropatana Bunge. Nat Prod Res. 26:1910-1913.

[20] Mahato SB, Kundu AP.1994. ${ }^{13}$ C NMR spectra of pentacyclic triterpenoids - a compilation and some salient features. Phytochemistry 37:1517-1575.

[21] Ikuta A, Itokawa H. 1989. 30-Noroleanaane saponins from callus tissues of Akebia quinata. Phytochemistry 28:2663-2665.

[22] Jang SE, Jeong JJ, Hyam SR, Han MJ, Kim DH. 2014. Ursolic acid isolated from the seed of Cornus officinalis ameliorates colitis in mice by inhibiting the binding of lipopolysaccharide to Toll-like receptor 4 on macrophages. J Agric Food Chem. 62:97119721.

[23] Saeidnia S, Moradi-Afrapoli F, Gohari AR, Malmir R. 2009. Cytotoxic flavonoid from Achillea talagonica Bioss. J Med Plants. 8:52-56.

[24] Lee MH, Son YK, Han YN. 2002. Tissue factor inhibitory flavonoids from the fruits of Chaenomeles sinensis. Arch Pharm Res.25:842-850. 
[25] Gohari AR, Ebrahimi H, Saeidnia S, Foruzan M, Ebrahimi P, Ajani Y. 2011. Flavones and flavone glycosides from Salvia macrosiphon Boiss. Iran J Pharm Res. 10:247-251.

[26] Han XH, Hong SS, Hwang JS, Lee MK, Hwang BY, Ro JS. 2007. Monoamine oxidase inhibitory components from Cayratia japonica. Arch Pharm Res.30:13-17.

[27] Bruno M, Savona G, Hueso-Rodriguz JA, Pascwal C, Rodriguez B. 1987. Ursane and oleanane triterpenoids from Salvia argentea. Phytochemestry 26:497-501. 

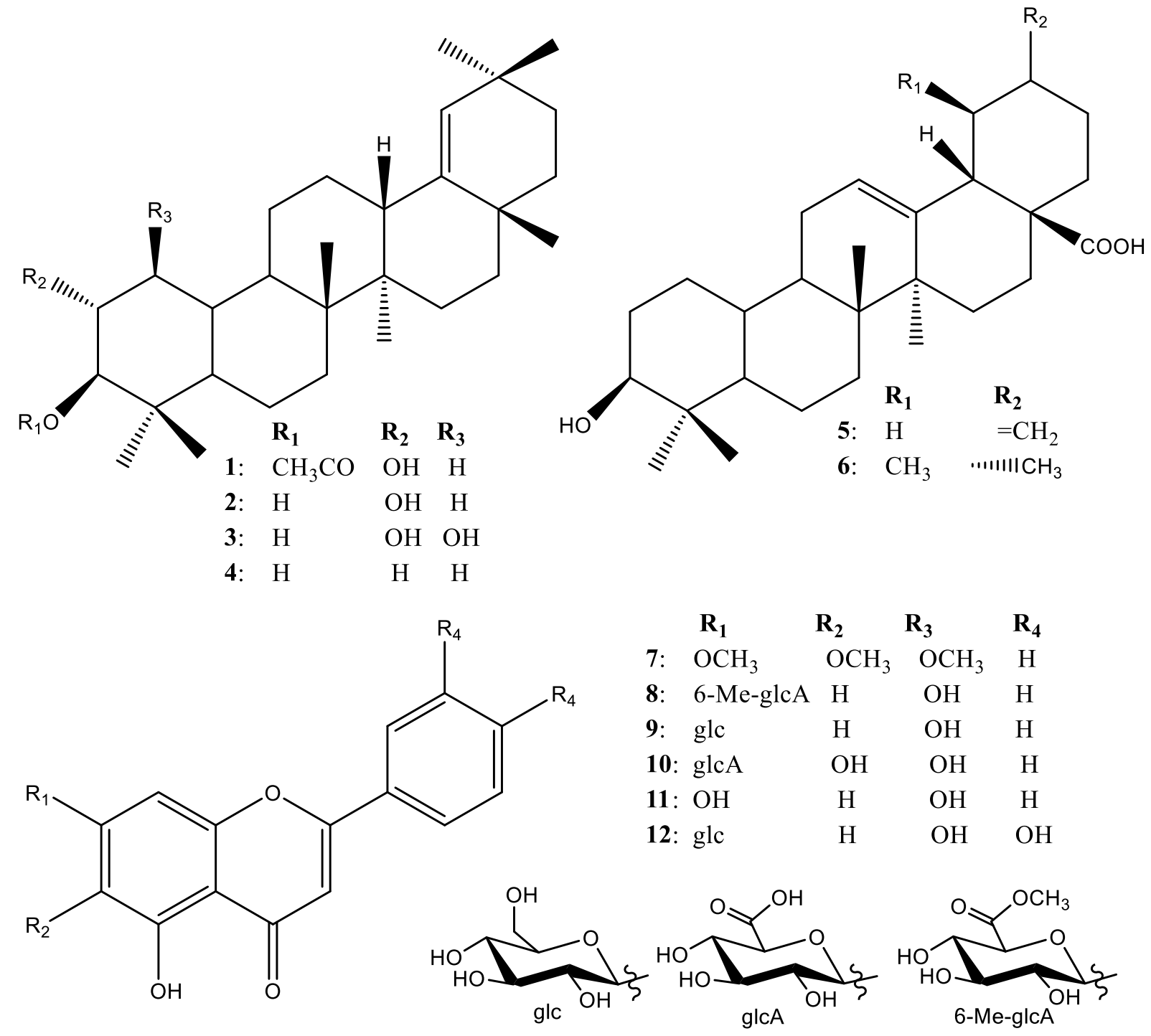

Figure 1. Chemical structures of compounds 1-12 isolated from Salvia barrelieri. 
Table 1.

Minimum inhibitory concentration (MIC) values in liquid medium and cytotoxic activity against HT1080, HL60 and K562cell lines of compounds isolated from S.barrelieri.

\begin{tabular}{|c|c|c|c|c|c|c|c|}
\hline \multirow[b]{3}{*}{ Compounds } & \multicolumn{5}{|c|}{ Antibacterial activity } & \multirow{2}{*}{\multicolumn{2}{|c|}{$\begin{array}{c}\text { Cytotoxic activity } \\
\text { IC }(u \mathbf{M})\end{array}$}} \\
\hline & \multicolumn{5}{|c|}{ CMI $(\mu \mathrm{g} / \mathrm{mL})$} & & \\
\hline & E. faecalis & S. aureus & E. coli & S. epidermis & P. aeruginosa & HL60 & K562 \\
\hline 1 & $>500$ & $>500$ & $>500$ & $>500$ & $>500$ & $>100$ & $>100$ \\
\hline 2 & 125 & 62.5 & 125 & 62.5 & 62.5 & $54 \pm 0.8$ & $85 \pm 1.6$ \\
\hline 3 & $>500$ & $>500$ & $>500$ & $>500$ & $>500$ & $>100$ & $>100$ \\
\hline 4 & $>500$ & $>500$ & $>500$ & $>500$ & $>500$ & $42 \pm 0.6$ & $82 \pm 1.4$ \\
\hline 5 & 125 & 250 & 250 & 125 & 250 & $52 \pm 0.9$ & $82 \pm 1.0$ \\
\hline 6 & 31.2 & 125 & 500 & 250 & 125 & $>100$ & $>100$ \\
\hline 7 & $>500$ & $>500$ & $>500$ & $>500$ & $>500$ & $>100$ & $>100$ \\
\hline 8 & 500 & 125 & 500 & 500 & 250 & $>100$ & $>100$ \\
\hline 9 & $>500$ & $>500$ & $>500$ & $>500$ & $>500$ & $>100$ & $>100$ \\
\hline 10 & 31.2 & 125 & 31.2 & 31.2 & 15.1 & $>100$ & $>100$ \\
\hline 11 & $>500$ & $>500$ & $>500$ & $>500$ & $>500$ & $>100$ & $>100$ \\
\hline 12 & 31.2 & 250 & 31.2 & 31.2 & 31.2 & $>100$ & $>100$ \\
\hline Gentamicin $^{\mathbf{a}}$ & 16 & 4 & 4 & 0.25 & 8 & - & - \\
\hline Vancomycin $^{\mathrm{a}}$ & $>64$ & $>64$ & 16 & 4 & $>64$ & - & - \\
\hline Campthotecin ${ }^{\mathrm{a}}$ & - & - & - & - & - & $0.25 \pm 0.03$ & $0.30 \pm 0.05$ \\
\hline
\end{tabular}

ased as positive control 